\title{
Future Impact on Maharagama Town Traffic Flow and Pedestrian Safety due to Southern Expressway and Outer Circular Highway: Proposed Solutions
}

\author{
A. S. Amarasinghe, A. I. Gurusinghe and K. S. Weerasekera
}

\begin{abstract}
Maharagama town becomes severely congested due to traffic \& pedestrian activities during daytime. The absence of proper road shoulders makes the pedestrians enter the carriageway, which in turn creates a safety hazard and results in slowing down vehicular traffic. After the completion of the Southern Expressway and Outer Circular Highway, it is expected that additional traffic volume in Maharagama town area will result in traffic congestion and safety situation even worse. In order to find a solution for this situation, capacities of roads were evaluated by compiling data of vehicular flow, pedestrian movements and other supportive information of that area for present condition and for year 2030 (i.e. 20 years from now) with do nothing option.
\end{abstract}

According to the obtained field data, and capacity calculations, all the roads in this area will badly fail to cater to the future traffic demand (i.e. for year 2030) unless some drastic improvements are conducted immediately. Also it was found that even at present, available pedestrian facilities were not satisfactory in this area, and the rate of accidents were high. Hence road widths, number of lanes, walkway shoulders, and pedestrian crossings were designed using the US highway capacity manual to evaluate the above conditions in the zone. Also geometric designs for islands were conducted based on AUSTROADS guides and templates. Objective of this study is to introduce suitable layout plan for Maharagama town area with required road improvements, road signs, and pedestrian facilities to enhance traffic flow and pedestrian safety for future operational conditions with the Southern Expressway and Outer Circular Highway in operation.

Keywords: Maharagama Town Traffic, Southern Expressway, Outer Circular Highway

\section{Introduction}

Maharagama town is administered by the Maharagama Urban Council and it's situated around A4 (High Level Road), about $15 \mathrm{~km}$ away from the centre of the commercial capital Colombo. Town area governed by the Maharagama Urban Council and is around $1.245 \mathrm{~km}^{2}$.

As Figure 1 indicates, the study area was selected between Maharagama Bo-tree junction (A) to President's College junction (C) along Old Road (distance of about $800 \mathrm{~m}$ ) and along High Level Road (distance of $820 \mathrm{~m}$ ). Administrative authority of these two main roads is the Road Development Authority. In the selected study area there are four main three legged intersections. They are Bo-tree junction (A), Pamunuwa junction (B), President's College junction (C) and Clock tower junction (D) as indicated in Figure 1.

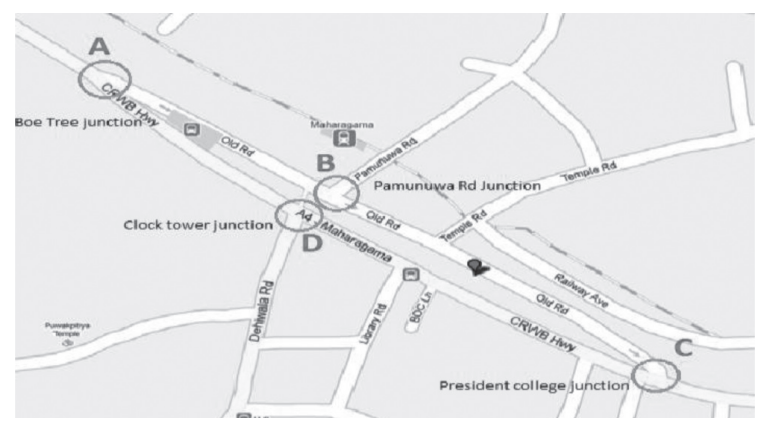

Figure 1 - Location of the study area (Source: [7])

A. S. Amarasinghe, BTech (Eng) (Hon) (OUSL), Department of Civil Engineering, The Open University of Sri Lanka

A. I. Gurusinghe, Undergraduate, Department of Civil Engineering, The Open University of Sri Lanka.

Eng. (Prof.) K. S. Weerasekera, BSc Eng (Moratuwa), MEngSc (UNSW), PhD (UNSW), FIE (Sri Lanka), CEng, IntPE(SL), MIE (Aust), CPEng, MIHT (UK), MASCE, Professor in Civil Engineering, Department of Civil Engineering, The Open University of Sri Lanka. 
The Colombo-Matara Highway (also known as the Southern Expressway) is partially constructed at present. This will link the Sri Lankan capital Colombo with Matara, a major city in the south of the country. This $128 \mathrm{~km}$ expressway once fully completed will be $26 \mathrm{~m}$ wide, (ie. Including 3 lanes each direction, centre-median, and 2 emergency lanes on either side). Initially it will have 4 lanes up to Galle from Makumbura with the remainder having 2 lanes. The entire expressway will later be widened to six lanes [1].

Outer Circular Highway $(\mathrm{OCH})$ is an access control road encircling Colombo. The $29 \mathrm{~km}$ (18 mile) long Outer Circular Road will connect with proposed Colombo-Matara Expressway and with proposed Colombo-Katunayake Expressway (under construction) and will provide an orbital beltway to bypass the city of Colombo. On completion, this highway will provide access to existing national highways (i.e. A and B class roads) and proposed expressways at several interchanges, and as such will serve as the basis for the entire network of highways and expressways in the country [1]. The main objective of the Outer Circular Highway is to disperse traffic congestion and encourage development away from the highly populated urban areas in the western province achieving a better balance for physical and economic growth.

It is observed that during peak hours Maharagama town area gets severely congested due to traffic \& pedestrian activities. As a solution currently a one-way road system is introduced around Maharagama, but still the problem is not addressed completely. Therefore people waste time on the road which they could use more productively when passing Maharagama town.

Southern Expressway starts from Makumbura interchange which is located east of Kottawa town. This interchange is also a continuation of Outer Circular Highway. After construction of the Southern Expressway and Outer Circular Highway, it can be expected to create a certain volume of additional traffic to the High Level Road. Initially Southern Expressway will have four lanes but later will be expanded to six lanes which may influence to increase to a high level of traffic as mentioned above. Traffic that travels along Outer Circular Highway and Southern Expressway to Colombo and from Colombo to these highways has to pass through Maharagama town. Hence the traffic congestion around Maharagama town will be worse in the future unless a proper solution is given.

Also the road shoulders in Maharagama town are often encroached by wayside traders, hawkers \& other businesses for private use. The absence of proper road shoulders makes the pedestrians enter the carriageway, which in turn creates another safety hazard and results in slowing down vehicular traffic. Maharagama roads within our study area do not have adequate road width even to allow parking on one side of the road besides on both sides. But haphazard and illegal parking is commonly contributing to traffic congestion in the area.

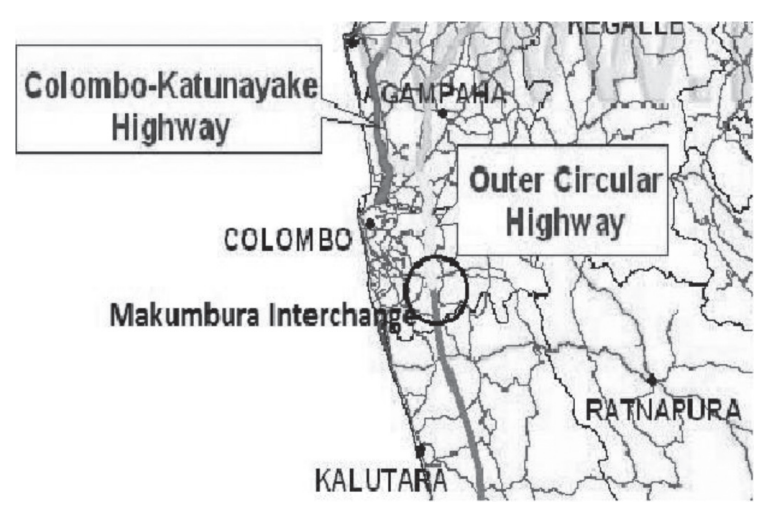

Figure 2 - Makumbura interchange (Source: [1])

\section{Aim and Objectives}

The Maharagama town area is already congested by traffic and pedestrian activities. One of the major problems for congestion at Maharagama town is because of excessive pedestrian movements taking place due to number of wayside textile traders occupying Maharagama town area as their business grounds. Also this business community disturbs the walkways and pedestrians have to use the carriageways for their movements. The obvious solution for this situation is, to transfer this business activity away from the congested locations. Also unavailability of a central bus stand is causing a major transportation issue in Maharagama. This has resulted in large amount of cross transfers across the roads. In future, according to the normal growth, the traffic volume will rapidly increase. In addition, after the implementation of the Southern Expressway and Outer Circular Highway it can be expected to create a high 
volume of additional traffic to the roads within the study area.

The aim of this study is to identify whether the existing road capacities are enough to cater to the current traffic volume and also for the future traffic. Then to Explore possibility to improve the roads by introducing suitable road widths and number of lanes at study area to cope with the traffic needs at a reasonable level of service, while enhancing the safety of pedestrians.

In achieving the above aim, there are some interim objectives that have to be satisfied. Following concerns have been addressed in this study.

1. To check whether the road capacities are adequate to cater to the current traffic volume in Maharagama town area.

2. Design the roads in Maharagama town area for year 2030 with a suitable level of service to cater to normal \& additional traffic from Southern Expressway \& Outer Circular Highway.

3. Design the islands by conducting turning movement surveys at main intersections as an alternative method to improve and streamline the traffic flow.

4. Design of pedestrian crossings \& walkways within the study area to suit the pedestrian activity in the area.

5. Conduct an accident study in the specific area and propose remedial measures by identifying the black spots.

6. Prepare a suitable layout plan for Maharagama town area which satisfies the above requirements.

\section{Methodology}

\subsection{Data from relevant institutions}

Relevant data was collected from Urban Development Authority of Sri Lanka, Road Development Authority of Sri Lanka, Maharagama Urban Council, Maharagama Police Station, Southern Transport Development Project, and Outer Circular Road Project.

\subsection{Traffic and pedestrian studies}

Following traffic data gathering exercises were conducted.

- Measure the volume of daily traffic flow according to vehicle types on relevant roads in Maharagama.

- Identification of peak flows.

- Conduct turning movement surveys.

- Conduct highway capacity analysis.

- Carry out pedestrian volume surveys.

- Conduct pedestrian travel pattern studies.

\subsection{Accident study}

- Collect accident records from Maharagama Police Station.

- Identify the high risk accident locations. (i.e. Black spots).

- Ranking them using suitable method.

- Recommend proper treatments to those accident prone locations.

\subsection{Capacity checks}

Highway capacity checks were conducted for High Level Road, Old Road, Dehiwala Road, and Pamunuwa Road for the present and future traffic flows to check on their satisfactory performance. These roads were evaluated to see whether they could carry the flows satisfactorily. During the study if found that road widths and lanes do not satisfactorily cater to the future traffic, they were redesigned using the highway capacity manual.

Pedestrian data was obtained by conducting pedestrian surveys and analyzed these data to check the pedestrian safety with increasing population and traffic growth for year 2030. Crosswalks and sidewalks were redesigned after checking for population growth, since it was found that present facilities and conditions were not of acceptable standards. Traffic and pedestrian islands were designed to provide pedestrian safety and to minimize accidents in this study area.

Also field surveys were done to evaluate the dimensions of roads and pedestrian crossings 
within the study area at present. Furthermore turning movement surveys were carried out.

\section{Data and Analysis}

\subsection{Identification of peak hour}

From the 24 hour MCC traffic data, morning, mid-day and evening peak hours within the study area were identified. There were two major peak hour ranges; morning peak from 7.30 to 8.30 am and the evening peak from 17.30 to $18.30 \mathrm{pm}$. Since, Maharagama town area experienced heavy traffic (both vehicular and pedestrian) during mid-day, the field studies were also focused during the day time too.

\subsection{Distance between intersections and pedestrian crossings.}

Distances between intersections and crossings were measured and are indicated in Figure 3 below.

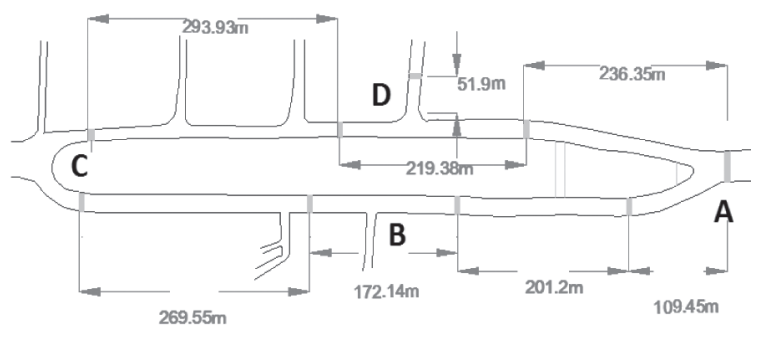

Figure 3 - Locations of pedestrian crossings.

\subsection{Pedestrian volume}

Pedestrian surveys were conducted at $75 \mathrm{~m}$ stretches. Pedestrian crossings taking place (in both directions) at 5 minute intervals were recorded separately on High Level Road, Old Road, Dehiwala Road, and Pamunuwa Road within the study area. This gave us a good insight of the pedestrian crossings taking place in the study area and a basis to design the proposed pedestrian crossings.

\subsection{Accident data}

The police usually maintain daily accident records. It contains the date, time, location, nature of accident and elements involved. Three natures of accidents were categorized as; Fatal, Grievous, and Light. Data within four years (from 2007 onwards) was collected.

\subsection{The traffic volume forecast}

Using the present traffic volumes and relevant growth factors obtained from RDA future traffic in the study area was computed. This helped to foresee the traffic demand in another 15 to 20 years from now. This in turn helps to decide the highway capacity at a suitable level of service for the predicting time period.

Figure 4 indicates the peak hour traffic volumes that would be added to the High Level Road due to the Southern Expressway and Outer Circular Highway in year 2030 [4, 5]. Morning peak hour flows were taken towards Colombo direction and evening peak hour flows were taken in the opposite direction.

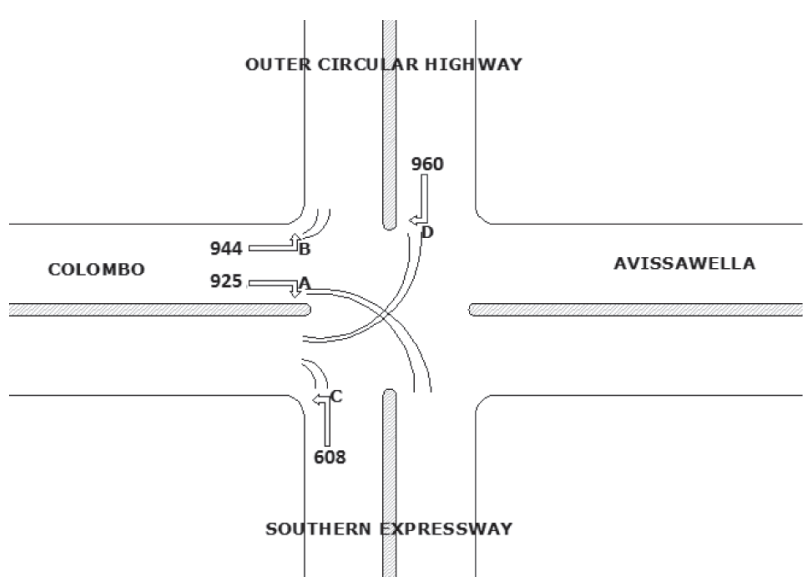

Figure 4 -Peak hour flows in Makumbura interchange at year 2030

Traffic volume forecast for year 2030 at Makumbura interchange (without the two new roads) was computed with equation shown below [4].

$$
\begin{aligned}
& (\mathrm{PHV})_{\text {future }}=(\mathrm{PHV})_{\text {present }} \times(1+\mathrm{g})^{\mathrm{n}} \\
& \mathrm{PHV} \quad=\text { Peak Hour Volume } \\
& \mathrm{g} \quad=\text { Annual growth factor. } \\
& \mathrm{n} \quad=\text { Number of years }
\end{aligned}
$$

The additional traffic from the two new roads was then taken into consideration in obtaining the new volumes. Finally total volumes were computed.

\subsection{Capacity analysis.}

Road capacity checks were carried-out for the High Level Road, Old Road, Pamunuwa Road and Dehiwala Road using US highway capacity manual [7]. Level of services for each road segments were checked for existing traffic conditions. Initially capacities were checked for current traffic condition in above four roads. Then it will be continued for High Level Road and Old 
Road, considering both normal traffic and additional traffic from Southern Expressway and Outer Circular Highway in year 2030.

\subsection{Design of road widths and introduction of additional lanes}

From the above capacity analysis results, by considering impact of traffic from Southern Expressway and Outer Circular Highway, it was proposed to improve the study area roads by introducing suitable road widths and sufficient number of lanes to cope with the traffic needs at a meaningful level of service.

\subsection{Level of service criteria}

Level of service criteria for multilane and two lane highways are defined in terms of density [5]. Complete Level of Service (LOS) criteria are given in US highway capacity manual for $70 \mathrm{mph}, 60 \mathrm{mph}$ and 50mph design speed elements. That gives the average travel speed, the maximum service flow rate, Maximum Servoce Flow, for each level of service. The maximum service flow rates are stated in terms of rates of flow for the peak $15 \mathrm{~min}$. Demand or forecasted volumes will be divided by the peak hour factor to reflect a maximum flow rate. High-level Road, Old Road and Dehiwala Road will be considered as multilane highways and Pamunuwa Road is the two lane highway. In this study, for capacity analysis both of the above mentioned criteria were used [5].

\subsection{Capacity analysis of the Old Road (multilane highway)}

Old Road in Maharagama town area was considered as a multilane highway, and capacity checks were conducted as per US highway capacity manual (1985) [5].

$$
\begin{aligned}
& \mathrm{SF}_{\mathrm{i}}=\mathrm{MSF}_{\mathrm{i}} \times \mathrm{N} \times \mathrm{f}_{\mathrm{w}} \times \mathrm{f}_{\mathrm{HV}} \times \mathrm{f}_{\mathrm{E}} \times \mathrm{f}_{\mathrm{P}} \\
& \mathrm{MSF}_{\mathrm{i}}=\mathrm{c}_{\mathrm{j}} \times(\mathrm{v} / \mathrm{c})_{\mathrm{i}} \\
& \mathrm{SF}_{\mathrm{i}}=\mathrm{c}_{\mathrm{j}} \times(\mathrm{v} / \mathrm{c})_{\mathrm{i}} \times \mathrm{N} \times \mathrm{f}_{\mathrm{w}} \times \mathrm{f}_{\mathrm{HV}} \times \mathrm{f}_{\mathrm{E}} \times \mathrm{f}_{\mathrm{P}}
\end{aligned}
$$

$\mathrm{SF}_{\mathrm{i}}=$ Service flow rate; the maximum flow rate that can be accommodated by the multilane highway, in one direction, under prevailing roadway and traffic conditions, while meeting the performance criteria of $\operatorname{LOS}_{\mathrm{i}}$ in $\mathrm{vph}$

$\mathrm{MSF}_{\mathrm{i}}=$ Maximum service flow rate; the maximum rate of flow which can be accommodated by the multilane highway segment. $\mathrm{c}_{\mathrm{j}} \quad=$ Capacity per lane for a multilane highway with design speed J: 2000 pcphpl for $\mathrm{j}=70 \mathrm{mph}$ or $60 \mathrm{mph}, 1900$ pcphpl for $\mathrm{j}=50 \mathrm{mph}$

$\mathrm{N}=$ Number of lanes in one direction

$(\mathrm{v} / \mathrm{c})_{\mathrm{i}}=$ Maximum volume-to-capacity ratio allowable while maintaining the performance characteristics of $\mathrm{LOS}_{\mathrm{i}}$

$\mathrm{f}_{\mathrm{w}} \quad=$ Adjustment factor for lane width

$\mathrm{f}_{\mathrm{HV}}=$ Adjustment factor for the presence of heavy vehicles in the traffic stream

$\mathrm{f}_{\mathrm{E}} \quad=$ Adjustment factor for the development environment and type of multilane in the traffic stream

$\mathrm{f}_{\mathrm{P}}=$ Adjustment factor for driver population

4.10 Capacity analysis for present condition of Old Road with normal traffic and additional traffic at year 2030

Road width

$=34 \mathrm{ft}(10.36 \mathrm{~m})$

Shoulder width $\quad=4.27 \mathrm{ft}(1.3 \mathrm{~m})$

No of lanes $\quad=3$

Full hour volume $\quad=4092 \mathrm{vph}$

Maximum $15 \mathrm{~min}$ volume $\quad=1138 \mathrm{vph}$

Lane width

$=(34 \mathrm{ft} / 3)=$

$11.33 \mathrm{ft}(3.45 \mathrm{~m})$

Peak hour factor $\quad=($ full hour

volume/4 × Maximum 15 min volume)

Service flow rate $=$ Full hour volume $/$ Peak hour factor $=4092 /(4092 / 4 \times$ 1138) $=4552 \mathrm{vph}$

When using the US highway capacity manual for capacity calculation it takes care of several adjustment factors, such as; lane width or lateral clearence restrictions $\left(f_{w}\right)$, presence of heavy vehicles in the traffic stream $\left(\mathrm{f}_{\mathrm{HV}}\right)$, environment and type of the multilane highways $\left(\mathrm{f}_{\mathrm{E}}\right)$, and driver population $\left(\mathrm{f}_{\mathrm{P}}\right)$ which are affected by prevailing conditions that are not 'ideal'.

$\mathrm{f}_{\mathrm{w}}=0.961$ (by linear interpolation)

Consider commuter and regular users.

$\mathrm{f}_{\mathrm{p}}=1.00$

Multilane highway is undivided and suburban $\mathrm{f}_{\mathrm{E}}=0.8$ 
Computation for the heavy vehicle adjustment factor $f_{h v}$ was now carried out after determining passenger car equivalent for trucks (ET) and buses (EB) and also proportion of trucks and buses in the traffic stream which were PT and PB.

$$
\begin{aligned}
& \mathrm{f}_{\mathrm{HV}}=1 /\{1+\mathrm{PT}(\mathrm{ET}-1)+\mathrm{PB}(\mathrm{EB}-1)\} \\
& \mathrm{ET}=1.7, \mathrm{~EB}=1.5, \mathrm{PT}=0.09, \mathrm{~PB}=0.1, \text { and } \\
& \mathrm{f}_{\mathrm{HV}}=0.898 \\
& \mathrm{v} / \mathrm{c}=\mathrm{SF}_{\mathrm{i}} / \mathrm{c}_{\mathrm{j}} \times \mathrm{N} \times \mathrm{f}_{\mathrm{w}} \times \mathrm{f}_{\mathrm{E}} \times \mathrm{f}_{\mathrm{p}} \times \mathrm{f}_{\mathrm{HV}} \\
& \mathrm{c}_{\mathrm{j}}=2000 \mathrm{pcphpl} . \\
& \mathrm{v} / \mathrm{c}=4552 /(2000 \times 3 \times 0.961 \times 0.898 \times 0.8 \times 1) \\
& \mathrm{v} / \mathrm{c}=1.09
\end{aligned}
$$

1.09 volumes to capacity ratio belong to level of service $\mathrm{E}$.

Hence present conditions of Old Road were not satisfactory to cater the future traffic demand to maintaining level of service D.

\subsection{Redesign of Old Road with normal traffic and additional traffic at year 2030}

Capacity analysis for Old Road,

Considering morning peak hour (the worst scenario)

$$
\begin{aligned}
& \text { Full hour volume } \quad=4092 \mathrm{vph} \\
& \text { Full hour volume } \quad=5013 \text { pcuph } \\
& \mathrm{PT}=0.09, \quad \mathrm{~PB}=0.1, \mathrm{f}_{\mathrm{HV}}=0.898, \mathrm{f}_{\mathrm{E}}=0.8 \text {, } \\
& \mathrm{f}_{\mathrm{P}}=1.00
\end{aligned}
$$$$
\text { Design level of service is } \mathrm{D} \text {, }
$$$$
\mathrm{v} / \mathrm{c}=0.8
$$$$
\text { Design speed } \quad=60 \mathrm{mph}(96.56 \mathrm{kmph})
$$$$
\mathrm{MSF}_{\mathrm{i}}
$$$$
=1600
$$$$
\text { Design lane width } \quad=12 \mathrm{ft}(3.66 \mathrm{~m})
$$$$
\text { Design shoulder width }=6 \mathrm{ft}(1.82 \mathrm{~m})
$$$$
\text { Hence } \mathrm{f}_{\mathrm{w}}=1
$$$$
\mathrm{SF}_{\mathrm{i}}
$$$$
=5013 \text { pcu (Service }
$$

flow rate on Old Road at year 2030)

$$
\begin{aligned}
\mathrm{N} & =\mathrm{SF}_{\mathrm{i}} /\left(\mathrm{MSF}_{\mathrm{i}} \times \mathrm{f}_{\mathrm{W}} \times \mathrm{f}_{\mathrm{HV}} \times \mathrm{f}_{\mathrm{E}} \times \mathrm{f}_{\mathrm{P}}\right) \\
\mathrm{N} & =5013 /(1600 \times 1 \times 0.898 \times 0.8 \times 1) \\
\mathrm{N} & =4.36
\end{aligned}
$$

$$
\begin{array}{ll}
\text { Designed no of lanes } & =5 \\
\text { Designed road width } & =60 \mathrm{ft}(18.29 \mathrm{~m})
\end{array}
$$

4.12 Capacity analysis of the Pamunuwa

Road (two-lane, two-way highway)

Pamunuwa Road is the minor road segment in Maharagama area and additional traffic from Southern Expressway and Outer Circular Highway does not directly impact on the road. It is a two lane highway and necessary to do the capacity check on normal traffic growth for 2030 year.

Total two way hourly volume on Pamunuwa Road was 1932 vph. Using the highway capacity manual taken the peak hour factor, $1932 \mathrm{vph}>1900 \mathrm{vph}$. Hence peak hour factor was 0.96

According to the turning movement survey details, directional split of traffic on Pamunuwa Road was taken as 60/40. Therefore adjustment factor for directional distribution $\mathrm{f}_{\mathrm{d}}$ was taken as 0.94 using US highway capacity manual.Type of the terrain of Pamunuwa Road is level.

Actual flow rate = peak hour volume / peak hour factor

$$
\text { -- do -- } \quad=\mathrm{V} / \mathrm{PHF}
$$

Actual flow rate $=1932 \mathrm{vph} / 0.96$

$$
=2013 \mathrm{vph}
$$

Directional split was 60/40. Hence total capacity was 2300 pcph

$\mathrm{SF}_{\mathrm{i}}$

$$
=2650 \times(\mathrm{v} / \mathrm{c}) \times \mathrm{f}_{\mathrm{w}} \times \mathrm{f}_{\mathrm{HV}} \times \mathrm{f}_{\mathrm{d}}
$$$$
\mathrm{SF}_{\mathrm{i}}(\mathrm{LOS} \mathrm{A}) \quad=2650 \times 0.15 \times 0.937 \times 0.829 \times 0.94
$$$$
\mathrm{SF}_{\mathrm{i}}(\mathrm{LOS} \mathrm{A}) \quad=290 \mathrm{vph}
$$

Using the same method, service flow rates were calculated for LOS B, C, D, E and tabulated below.

Table 1 - Service flow rates for different LOS

\begin{tabular}{|c|c|c|c|c|c|}
\hline LOS & $\mathrm{v} / \mathrm{c}$ & $\mathrm{f}_{\mathrm{w}}$ & $\mathrm{f}_{\mathrm{hv}}$ & $\mathrm{f}_{\mathrm{d}}$ & $\begin{array}{c}\mathrm{SF}_{\mathrm{I}} \\
(\mathrm{vph})\end{array}$ \\
\hline $\mathrm{A}$ & 0.15 & 0.937 & 0.829 & 0.94 & 290 \\
\hline B & 0.27 & 0.937 & 0.800 & 0.94 & 504 \\
\hline C & 0.43 & 0.937 & 0.800 & 0.94 & 803 \\
\hline D & 0.64 & 0.937 & 0.829 & 0.94 & 1239 \\
\hline E & 1.00 & 0.976 & 0.829 & 0.94 & 2015 \\
\hline
\end{tabular}


When comparing these values with actual flow rate of year 2030 value (2013vph) this value was higher than the service flow rate for LOS D. Hence road segment was not adequate to cater to the traffic demand in year 2030. Hence, Pamunuwa Road also had to be designed as a multilane highway.

\subsection{Analysis of pedestrian crossings (for year 2030)}

All the crossings except the crossing in front of the supermarket were moderately affected due to vehicular traffic within peak hour. Hence they were analyzed as zebra crossings for year 2030. According to the pedestrian LOS criteria; designed level of service was taken as C [7].

Sample calculation for pedestrian crossing near temple road is stated below. In this calculation the highest pedestrian inbound volume and outbound volume were taken for year 2010 and extended to year 2030 volume using population growth factors.

According to the pedestrian LOS criteria

Pedestrian space $=24$ sq.ft $/$ ped (from US highway capacity manual)

Design width $=$ (Pedestrian per $\min$ $\times$ Pedestrian space) /Crossing width

Sample calculation for pedestrian crossing near temple road,

Highest inbound and outbound volume for 2010 (Vped 15min) = $=313$

Highest inbound and outbound volume for 2030 (Vped 15min) = $=414$

Pedestrians per minute $=414 / 15$

$$
=28 \mathrm{ped} / \mathrm{min}
$$

According to the pedestrian LOS criteria [7]

Pedestrian space $\quad=24 \mathrm{sqft} /$ ped

Design width $=($ Pedestrian per minute $\times$

Pedestrian space)/ Crossing width)

Designed width $=28 \times 24 / 60=11.2 \mathrm{ft}(3.41 \mathrm{~m})$

Pedestrian crossing in front of the supermarket greatly affected the vehicular traffic on High Level Road and vehicular traffic from Maharagama to Dehiwala. Also large numbers of pedestrian were using this pedestrian crossing. Hence it was decided to design it as a signalized pedestrian crossing.

\subsection{Check pedestrian crossing time for} signalized pedestrian crossing

When projected for a population growth rate of $1.4 \%$, a zebra crossing will not be sufficient for the pedestrian volume in 2030 in front of the super market. It exceeds the allowable width of the zebra crossing. Therefore when considering pedestrian safety with vehicular growth and population growth, its better to propose a pelican crossing in front of the super market.

Minimum pedestrian green time required for in front of the super market is

$$
\begin{array}{ll}
\mathrm{G}_{\mathrm{P}}=3.2 & +\mathrm{L} / \mathrm{S}_{\mathrm{p}}+\left(2.7 \mathrm{~N}_{\text {ped }} / \mathrm{W}_{\mathrm{E}}\right) \\
\mathrm{W}_{\mathrm{E}}>10 \mathrm{ft} & (3.05 \mathrm{~m})[6] \\
\mathrm{L} & =\text { Width of the road } \\
\mathrm{W}_{\mathrm{E}} & =\text { Width of the crossing } \\
\mathrm{G}_{\mathrm{P}} & =\text { Pedestrian green time. } \\
\mathrm{S}_{\mathrm{p}} & =\text { Pedestrian speed. } \\
\mathrm{N}_{\text {ped }} & =\text { Number of pedestrian per second. }
\end{array}
$$

$$
\begin{aligned}
& \mathrm{L}=18.29 \mathrm{~m}, \quad \mathrm{Sp}=1.2 \mathrm{~ms}-1, \quad \mathrm{~W}_{\mathrm{E}}=5 \mathrm{~m} \\
& \mathrm{G}_{\mathrm{P}}=3.2+18.29 / 1.2+[(2.7 \times 2) / 5] \\
& \mathrm{G}_{\mathrm{P}}=19.52 \mathrm{~s} \\
& \mathrm{G}_{\mathrm{P}}=20 \mathrm{~s}
\end{aligned}
$$

\subsection{Analysis of accident data}

Accident data of four years (2007 to 2011) was collected. Data on date of accident, time, location, elements involved and nature of accident were obtained. Locations were selected from data which had more than three accidents (ie. any type, either fatal, grievous or light) within four years. Those were identified as high risk accident locations. The distribution of types of accidents is shown in Figure 5 and the collision diagram is shown in Figure 6.

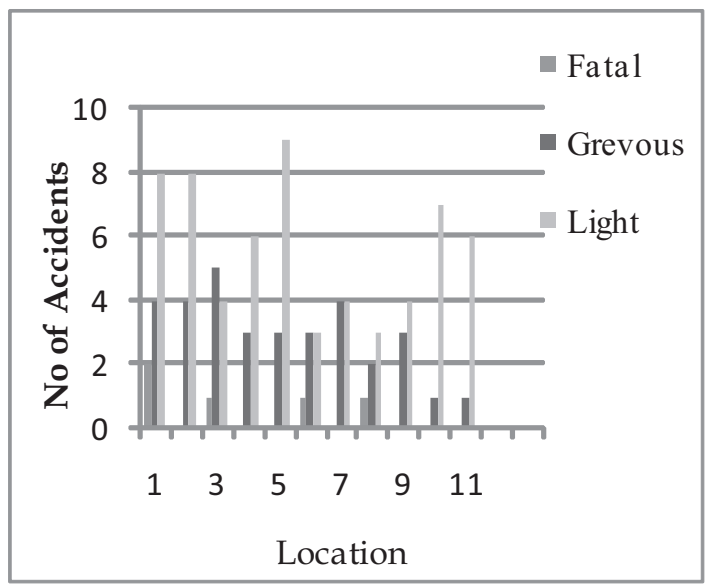

Figure 5 - Distribution of types of accidents 


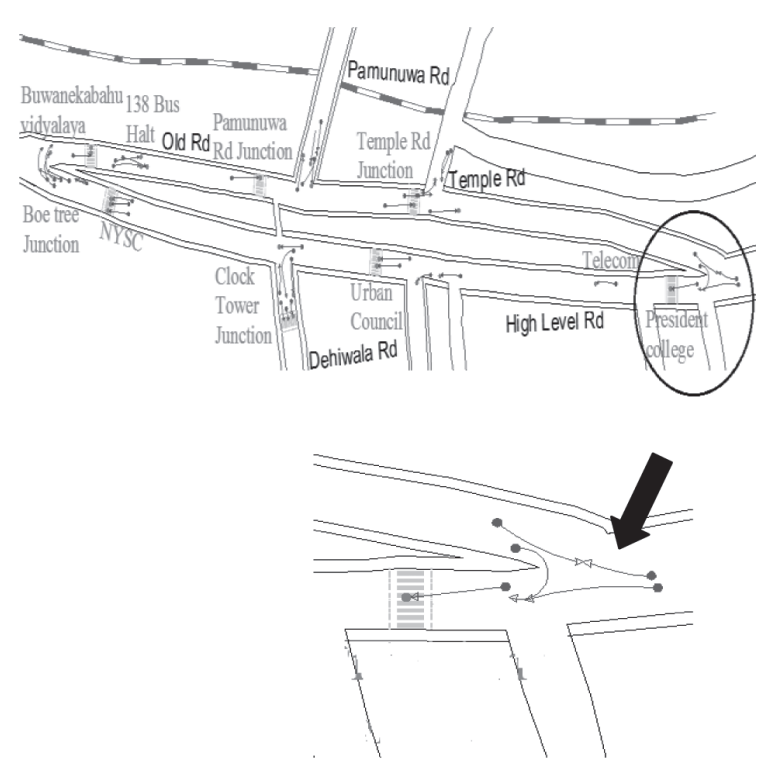

Figure 6 - Collision diagram

\subsection{Identification of black spots}

As per accident data from police records it was able to identify eleven high risk accident locations; which had more than three accidents within four years in study area. Weightages were given to different types of accidents and calculated the total weightage of each identified black spot locations and ranked them.

According to the gravity of accident category weightages of 5, 3 and 1 were assigned for Fatal, Grievous and Light respectively [3].

$P=X+3 \times Y+5 \times Z$, where

$X=$ total number of light injuries

$\mathrm{Y}=$ total number of grievous injuries

$\mathrm{Z}=$ total number of fatal injuries

Table 2 - High-risk accident locations

\begin{tabular}{|c|l|c|}
\hline No. & \multicolumn{1}{|c|}{ Location } & Weightage \\
\hline 1 & Pamunuwa Road junction & $(39)$ \\
\hline 2 & Old Road 138 bus stand & $(20)$ \\
\hline 3 & In front of NYSC & $(24)$ \\
\hline 4 & Temple Road junction & $(15)$ \\
\hline 5 & Clock tower junction & $(18)$ \\
\hline 6 & In front of urban council & $(24)$ \\
\hline 7 & Bo-tree junction & $(16)$ \\
\hline 8 & In front of president college & $(14)$ \\
\hline 9 & Near telecom & $(13)$ \\
\hline 10 & $\begin{array}{l}\text { Near Maharagama police } \\
\text { station }\end{array}$ & $(10)$ \\
\hline 11 & $\begin{array}{l}\text { In front of Buwanekabahu } \\
\text { vidyalaya }\end{array}$ & $(09)$ \\
\hline
\end{tabular}

When total accident weightage was greater than 15 it was taken as a black spot. Calculated weightages for each location were plotted and is shown in Figure 7.

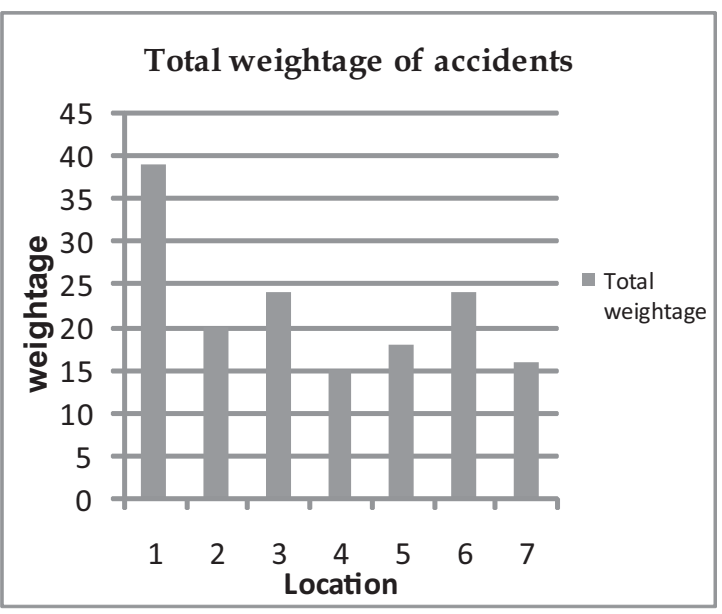

Figure 7- Accident weightage for each location

Analysing the above accident data, the following observations were made.

- Five fatal accidents had occurred within four year period in this study area.

- Most of the accidents were vehicle to vehicle and vehicle to pedestrian related.

- Most cases of pedestrians involving accidents had happened due to haphazard crossing of roads.

- Pamunuwa Road junction was the major area prone to accidents.

According to the above observations vehicle accidents in Maharagama area was not due to high speed driving of vehicles but due to congestion of moving vehicles and pedestrian movements. Most of the accidents occurring in this area is pedestrian involving accidents due to haphazard crossing of roads. Furthermore vehicle to vehicle accidents occurred at Boe tree junction, Clock tower junction, Pamunuwa Road junction and President's College junction with conflicting movements due to improper geometric design of above junctions. The walkways and carriageways need to be separated by a pedestrian protection fence at each junction, to avoid 
resort to the use of the roads which will increase the pedestrian's personal safety.

\subsection{Traffic island design}

Dehiwala Road junction, Bo-tree junction, Pamunuwa Road junction and President's College junction were redesigned using the AUSTROADS vehicles and turning path templates. For this design arterial/collector was used for the intersection road type and also single unit truck bus was used as the design vehicle. Normally turning speed of townships was $20 \mathrm{~km} / \mathrm{h}$. But Pamunuwa and Dehiwala are pedestrian congested junctions. Therefore when designing islands for Pamunuwa and Dehiwala junctions $5-15 \mathrm{~km} / \mathrm{h}$ turning speed was selected. Furthermore Botree and President's College junctions were adopted $0-5 \mathrm{~km} / \mathrm{h}$ turning speed due to geometry of them [8].

\subsection{Analysis of walkway widths}

Data were collected from the pedestrian surveys done during the peak hours around Maharagama area.

Sample calculation for Old Road:

For year 2010;

$$
\begin{array}{ll}
\mathrm{V} & =\mathrm{V}_{\mathrm{p} 15} / 15 \mathrm{~W}_{\mathrm{E}} \\
\mathrm{W}_{\mathrm{E}} & =\text { Effective walkway width } \\
\mathrm{W}_{\mathrm{T}} & =\text { Existing walkway width } \\
\mathrm{W}_{\mathrm{B}} & =\text { Reduction of walkway width } \\
\mathrm{W}_{\mathrm{E}} & =\mathrm{W}_{\mathrm{T}}-\mathrm{W}_{\mathrm{B}} \quad \text { Here, } \\
\mathrm{W}_{\mathrm{T}} & =4.3 \mathrm{ft}
\end{array}
$$

Width adjustment factors for walkways,

$$
\begin{array}{ll}
\mathrm{W}_{\mathrm{B}} & =2.5 \text { (for light poles) } \\
\mathrm{W}_{\mathrm{E}} & =4.3-2.5=1.8 \mathrm{ft} \\
\mathrm{V} & =537 / 15 \times(4.3-2.5)=20 \mathrm{ped} / \mathrm{min} / \mathrm{ft} \\
\mathrm{LOS} & =\mathrm{E}[7]
\end{array}
$$

By applying the population growth factor of $1.4 \%$, the estimated pedestrian flow in year 2030 is now calculated as:

$537 \times\left(1.014^{20}\right)=710$ ped $/ 15 \mathrm{~min}$

Hence in year 2030

The average unit width flow rate:

$$
\begin{aligned}
& \mathrm{v}=\mathrm{V}_{\mathrm{p} 15} / 15 \mathrm{~W}_{\mathrm{E}} \\
& \mathrm{W}_{\mathrm{E}} \quad=\text { Effective walkway width } \\
& \mathrm{W}_{\mathrm{T}} \quad=\text { Walkway width } \\
& \mathrm{W}_{\mathrm{B}} \quad=\text { Reduction of walkway width }
\end{aligned}
$$

$\mathrm{W}_{\mathrm{E}} \quad=\mathrm{W}_{\mathrm{T}}-\mathrm{W}_{\mathrm{B}} \quad$ Here,

$\mathrm{W}_{\mathrm{T}} \quad=6 \mathrm{ft}$ (designed walkway width in year 2030)

Width adjustment factors for walkways,

$$
\begin{array}{ll}
\mathrm{W}_{\mathrm{B}} & =2.5 \text { (for light poles) } \\
\mathrm{W}_{\mathrm{E}} & =6-2.5=3.5 \mathrm{ft} \\
\mathrm{V} & =\mathrm{V}_{\mathrm{p} 15} / 15 \mathrm{~W}_{\mathrm{E}} \\
\mathrm{V} & =710 / 15 \times(6-2.5)=13.5 \mathrm{ped} / \mathrm{min} / \mathrm{ft}
\end{array}
$$

LOS of pedestrian is $\mathrm{D}[7]$

For LOS C, Maximum pedestrian flow rate (v) $=10 \mathrm{ped} / \mathrm{min} / \mathrm{ft}[7]$

Hence $W_{\mathrm{T}}=[\{710 /(15 \times 10)\}+2.5]=7.2 \mathrm{ft}$

Design walkway width $\quad=7.2 \mathrm{ft}(2.19 \mathrm{~m})$

Using the same method, Design walkway widths were calculated for Old Road, HighLevel Road, Dehiwala Road and tabulated in Table B.4 in AppendixB.

\section{Conclusion}

\subsection{Improvement of roads in Maharagama town area}

High Level Road and Old Road are major roads in Maharagama town area. They will be directly influenced by additional traffic from Kottawa interchange after implementation of the Southern Expressway and Outer Circular Highway. In this study Maharagama town area with main approach roads to the High Level Road and Old Road was only considered. Also traffic volume from above approach roads which are Dehiwala Road and Pamunuwa Road was considered for designing all the roads in this area in year 2030. According to the collected and observed data and analysis carried out, it was observed that High Level Road and Old Road are not in a satisfactory condition to accommodate the additional traffic from Southern Expressway and Outer Circular Highway once they are in operation. Through this study, checks were done to observe the road capacities with current traffic in year 2010 and additional traffic due to Southern Expressway and Outer Circular Highway in year 2030. According to these checks it was found that present road capacities will not be sufficient to cater even the normal traffic growth of traffic on High Level Road (without any contribution from new roads) in year 2030 to function at a satisfactory level of service. Therefore to cater 
to the normal traffic growth and additional traffic from two new highways at year 2030, Old Road and High Level Road had to be redesigned as multilane highways by introducing new lane widths, road widths and by adding reasonable number of lanes to maintain a level of service D during the peak flows. Although level of service D is not a satisfactory condition, since it was considered for peak hours in year 2030 (worst scenario) it was accepted for this study.

Both Dehiwala and Pamunuwa Roads are two directional roads in Maharagama town area. But for normal traffic growth by year 2030 they also will find it difficult to cater to the above traffic with suitable level of service. Road capacities were checked for Dehiwala and Pamunuwa Roads and also designed as two directional highways by introducing new lane widths, road widths and by adding new lanes to operate at level of service D during peak flows. Designed road widths and lanes were stated in Table B-3 in Appendix B.

\subsection{Walkway shoulders and pedestrian safety}

Maharagama town area is a pedestrian congested area due to commercial buildings and wayside traders. The current walkway widths were utilized by unauthorized persons such as wayside traders and squatters. Therefore the walkway widths were reduced and as a result pedestrians tend to use the carriageway. Hence they lead to an unsafe situation. According to the US highway capacity manual all walkway shoulders in Maharagama town area was widened and also walkway shoulders and carriageways were separated by providing pedestrian safety fences at each junction. Designed walkway widths were stated in Table B-4 of Appendix B.

\subsection{Pedestrian crossings and pedestrian safety}

Zebra crossings were redesigned to improve the level of service of the pedestrians and also all the crossings were checked to identify the current level of service. Road signs were introduced at each pedestrian crossing to enhance the pedestrian safety. But maximum pedestrian volume was observed at the zebra crossing in front of the supermarket, and it was not enough to provide suitable level of service for pedestrians. Also this crossing was adversely affecting the vehicular flow on High Level Road causing excessive delays. Therefore pedestrian signalized crossing was introduced at that location to minimize the interruption of vehicular flow and to enhance the safety of pedestrians who used this crossing.

Furthermore black spot locations were identified in study area and according to the weightages they were ranked. According to the accident analysis most of accidents occurred when pedestrians were physically crossing the roads. Therefore road signs were provided to inform the drivers about the locations of the pedestrian crossings. On the other hand most of the accidents occurred due to absence of lane markings. Therefore proper lane markings were provided for all roads in Maharagama town area. Furthermore traffic islands were designed for main junctions to avoid traffic conflicts and also improve the pedestrian safety.

Acquisition of land and other related activities which creates social problems are involved in the widening of all roads in Maharagama town area. Therefore Old Road and High Level Road were redesigned with $12 \mathrm{ft}$ lane widths with five lanes. Pamunuwa Road was designed as a multilane highway consisting of 3 lanes for each direction with 10ft lane widths. Dehiwala Road was designed as a multilane highway with 3 lanes for each direction with $12 \mathrm{ft}$ lane widths. Maximum width of zebra crossing was designed as $5 \mathrm{~m}$ and other crossings were designed as $3 \mathrm{~m}$ or $4 \mathrm{~m}$ considering the relevant pedestrians volume.

\section{References}

1. http://www.rda.gov.lk RDA website, Sri Lanka. 2011.

2. Weerasekera, K. S. 'An Introduction to Traffic Engineering' Incolour (Pvt) Ltd., Colombo, 2009.

3. Wets, G, 'Black Zones: Black Spot Analysis Methods', 2003.

4. Feasibility Study Report of Southern Expressway, Road Development Authority, 1998.

5. Feasibility Study Report of Outer Circular Highway, Road Development Authority, 2000.

6. Mannering, Fred L., Kilareski, Walter P., Washburn, Scott, S., 'Highway Engineering 
and Traffic Analysis', 3rd ed. New Delhi: Wiley India (P) Ltd., 1997.

7. Transportation Research Board. Highway Capacity Manual. Special Report 209, Washington, D.C: National Research Council. 1994.

8. Rod George, PUB.RD.N.514. Austroads guide and commentary series. Sydney, ARRB Transport Research Ltd., 2005.

9. Chakroborty, P. 'Principles of Transportation Engineering'. 1st ed. New Delhi: Prentice-Hall of India Private Limited., 2003.

10. Weerasekera, K. S. 'Bridging the Gap towards Safer Roads - What is in between?', Proceedings of the UN-ESCAP Workshop on Developing Road Safety Strategy \& Goals, Ministry of Highways and Road Development, Government of Sri Lanka, 3rd December 2009. 


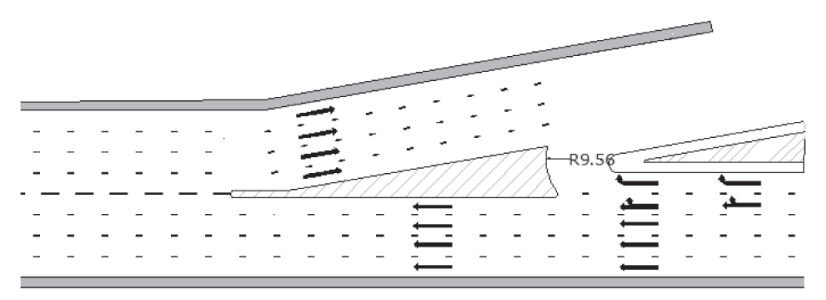

Figure A.1 - Island design for Boe tree junction

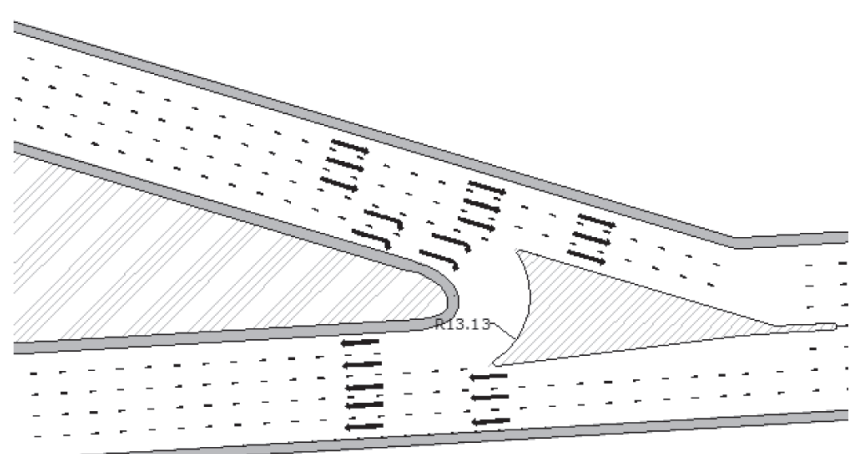

college junction

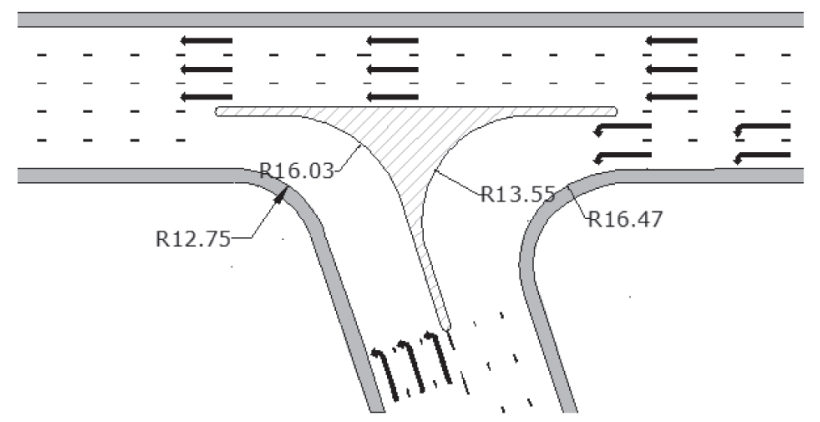

Figure A.3 - Island design for Dehiwala Road junction

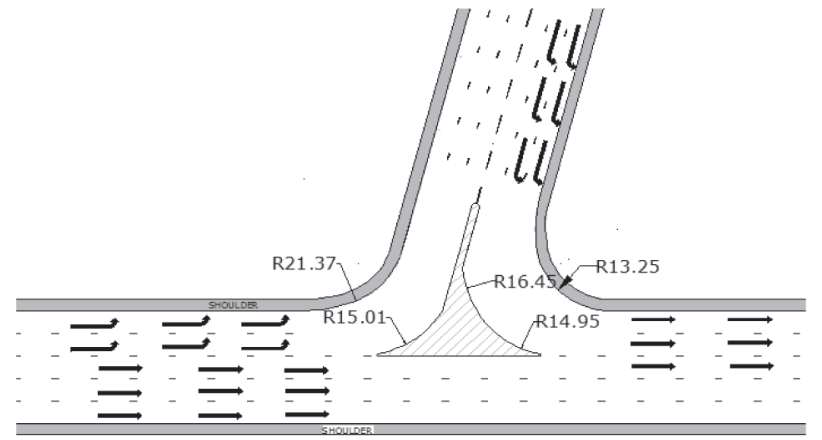

Figure A.4 - Island design for Pamunuwa Road junction

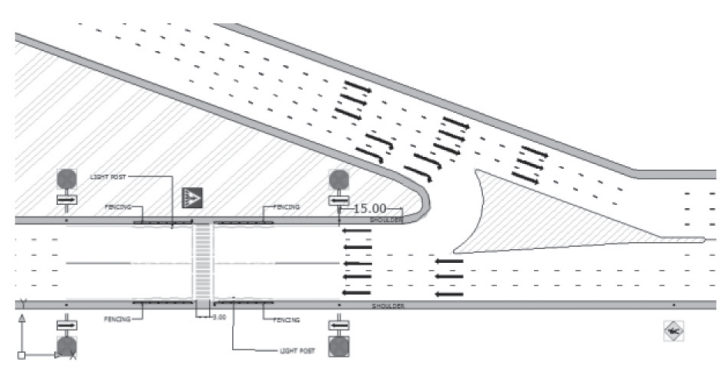

Figure A.5 - Final design for President's College junction

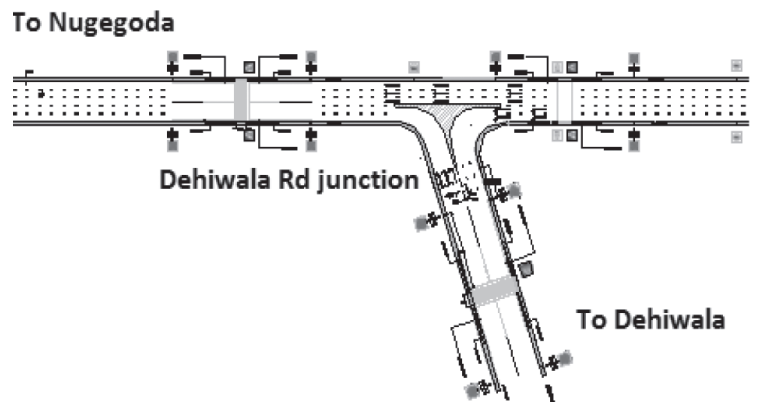

Figure A.6 - Final design for Dehiwala Road junction 


\section{APPENDIX - B}

Table B.1 - Total number of vehicles within

12 hour time period

\begin{tabular}{|c|c|c|c|}
\hline Time & \multicolumn{3}{|c|}{ Total no of vehicles } \\
\hline & $\begin{array}{c}\text { Maharagama } \\
\text { to Colombo }\end{array}$ & $\begin{array}{c}\text { Colombo to } \\
\text { Maharagama }\end{array}$ & $\begin{array}{c}\text { Two } \\
\text { directional } \\
\text { Total volume }\end{array}$ \\
\hline $7.00-8.00$ & 1776 & 730 & 2506 \\
\hline $7.30-8.30$ & $\mathbf{1 8 4 4}$ & $\mathbf{7 3 0}$ & $\mathbf{2 5 7 4}$ \\
\hline $8.00-9.00$ & 1625 & 672 & 2297 \\
\hline $9.00-10.00$ & 1177 & 720 & 1897 \\
\hline $10.00-11.00$ & 1019 & 850 & 1869 \\
\hline $11.00-12.00$ & 1052 & 819 & 1871 \\
\hline $12.00-13.00$ & 956 & 862 & 1818 \\
\hline $13.00-14.00$ & 763 & 872 & 1635 \\
\hline $14.00-15.00$ & 812 & 993 & 1805 \\
\hline $15.00-16.00$ & 778 & 888 & 1666 \\
\hline $16.00-17.00$ & 807 & 768 & 1575 \\
\hline $17.00-18.00$ & 733 & 1197 & 1930 \\
\hline $\mathbf{1 7 . 3 0 - 1 8 . 3 0}$ & $\mathbf{7 3 3}$ & $\mathbf{1 3 2 3}$ & $\mathbf{2 0 5 6}$ \\
\hline $18.00-19.00$ & 662 & 1323 & 1985 \\
\hline Total 12 & 14737 & 12747 & 27484 \\
\hline hour & & & \\
\hline
\end{tabular}

Table B.2- Pedestrian volume data at Clock tower junction

\begin{tabular}{|c|c|c|c|c|}
\hline $\begin{array}{c}5 \text { min } \\
\text { interval }\end{array}$ & \multicolumn{2}{|c|}{$\begin{array}{c}\text { At Morning } \\
\text { peak }\end{array}$} & \multicolumn{2}{c|}{$\begin{array}{c}\text { At Evening } \\
\text { peak }\end{array}$} \\
\hline & $\mathrm{V}_{\text {out }}$ & $\mathrm{V}_{\text {in }}$ & $\mathrm{V}_{\text {out }}$ & $\mathrm{V}_{\text {in }}$ \\
\hline 1 & 32 & 78 & 103 & 76 \\
\hline 2 & 31 & 82 & 127 & 80 \\
\hline 3 & 52 & 68 & 165 & 116 \\
\hline 4 & 24 & 69 & 98 & 67 \\
\hline 5 & 31 & 44 & 143 & 89 \\
\hline 6 & 45 & 46 & 102 & 34 \\
\hline 7 & 36 & 58 & 87 & 90 \\
\hline 8 & 26 & 54 & 120 & 57 \\
\hline 9 & 23 & 30 & 85 & 22 \\
\hline 10 & 39 & 37 & 198 & 83 \\
\hline 11 & 45 & 55 & 129 & 60 \\
\hline 12 & 39 & 39 & 95 & 14 \\
\hline
\end{tabular}

Table B.3 - Results of designed Road Widths and Lanes

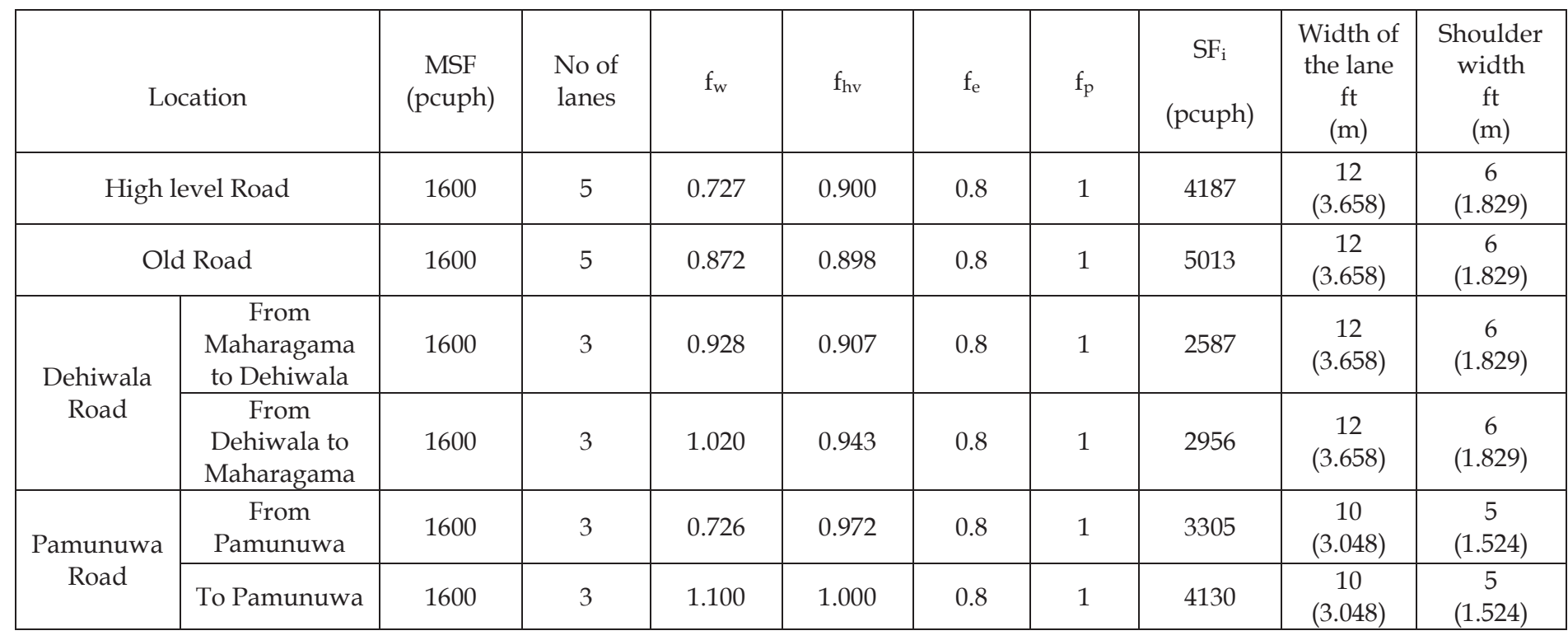


Table B.4- Pedestrian LOS for walkways

\begin{tabular}{|c|c|c|c|c|c|c|c|c|c|c|}
\hline \multirow[b]{2}{*}{ Location } & \multicolumn{4}{|c|}{ In 2010} & \multicolumn{4}{|c|}{ In 2030} & \multirow{2}{*}{$\begin{array}{c}\text { Designed } \\
\text { widths } \\
\text { W }_{\mathrm{T}} \\
\mathrm{Ft}(\mathrm{m})\end{array}$} & \multirow[b]{2}{*}{ LOS } \\
\hline & $\begin{array}{c}V_{\mathrm{p} 15} \\
\text { Ped/ } \\
15 \mathrm{~min}\end{array}$ & $\begin{array}{c}W_{\mathrm{E}} \\
\mathrm{ft}\end{array}$ & $\begin{array}{c}\mathrm{V} \\
\mathrm{ped} / \mathrm{min} \\
/ \mathrm{ft}\end{array}$ & LOS & $\begin{array}{c}\mathrm{V}_{\mathrm{p} 15} \\
\mathrm{Ped} / \\
15 \mathrm{~min}\end{array}$ & $\begin{array}{c}\mathrm{W}_{\mathrm{E}} \\
\mathrm{ft}\end{array}$ & $\begin{array}{c}\mathrm{V} \\
\mathrm{Ped} / \\
\mathrm{min} / \mathrm{ft}\end{array}$ & LOS & & \\
\hline Old Road & 537 & 1.8 & 20 & $\mathrm{E}$ & 710 & 3.5 & 13.5 & $\mathrm{D}$ & $\begin{array}{c}7.2 \\
(2.19)\end{array}$ & $\mathrm{C}$ \\
\hline $\begin{array}{l}\text { High- } \\
\text { Level } \\
\text { Road }\end{array}$ & 560 & 2.9 & 13 & D & 740 & 3.5 & 14.1 & $\mathrm{D}$ & $\begin{array}{c}7.4 \\
(2.26)\end{array}$ & $\mathrm{C}$ \\
\hline $\begin{array}{l}\text { Dehiwala } \\
\text { Road }\end{array}$ & 570 & 4.6 & 9 & $\mathrm{C}$ & 753 & 3.5 & 14 & $\mathrm{D}$ & $\begin{array}{l}7.52 \\
(2.29)\end{array}$ & $\mathrm{C}$ \\
\hline
\end{tabular}

